\title{
THE
}

\section{Liberty, Equality, Frivolity! An Italian Critique of Fashion Periodicals}

Catherine M. Sama

University of Rhode Island, csama@uri.edu

Follow this and additional works at: https://digitalcommons.uri.edu/ml_facpubs

Terms of Use

All rights reserved under copyright.

\section{Citation/Publisher Attribution}

Sama, C. M. "Liberty, Equality, Frivolity!: An Italian Critique of Fashion Periodicals." Eighteenth-Century Studies, vol. 37 no. 3, 2004, pp. 389-414. Project MUSE, doi:10.1353/ecs.2004.0032

Available at: http://dx.doi.org/10.1353/ecs.2004.0032

This Article is brought to you for free and open access by the Modern and Classical Languages and Literatures at DigitalCommons@URI. It has been accepted for inclusion in Modern and Classical Languages and Literatures Faculty Publications by an authorized administrator of DigitalCommons@URI. For more information, please contact digitalcommons-group@uri.edu. 


\section{$\mathcal{L}_{\text {iberty, Equality, Frivolity! }}$ An Italian Critique of Fashion Periodicals}

\section{Catherine M. Sama}

In the January 1777 issue of the Giornale enciclopedico, Venetian-born journalist Elisabetta Caminer Turra reviewed a book that had been translated from French into Italian by a woman from Vicenza. Caminer praised the anonymous translator for her intellectual accomplishments:

\footnotetext{
She has learned a foreign language, knows how to wield a pen, and knows how to sit at a writing table rather than at her toilette: as a result, she inspires the desire that is rare in women, that of seeing her make herself useful to her nation by translating works that can bring her real advantages or pleasures... ${ }^{1}$
}

By highlighting the contrast between the writing table and the toilette-between a useful life of intellectual work and a frivolous life focused on one's outward appearance-Caminer underscored her belief that the demands of the toilette were directly at odds with a life of independence and intellectual challenge for women. She made clear her conviction that a life of the mind could make women useful to their nation and, significantly, bring them personal pleasure and advantage.

Caminer knew well the "real advantages or pleasures" of which she wrote. She could have been describing herself in this passage, since by 1777 she was already an active participant in the Republic of Letters and well known by contemporaries as an "exception" to her sex. When she published this review she had

Catherine M. Sama is Associate Professor of Italian in the Department of Modern and Classical Languages and Literatures at the University of Rhode Island and the author of an anthology (in translation), Elisabetta Caminer Turra: Selected Writings of an 18th-Century Venetian Woman of Letters (Chicago: Univ. of Chicago Press, 2003). Her current research explores the network of Venetian women shaping culture and focuses on the painter Rosalba Carriera, the poet/playwright Luisa Bergalli Gozzi, and the journalist Elisabetta Caminer Turra.

Eighteenth-Century Studies, vol. 37, no. 3 (2004) Pp. 389-414. 
just assumed the direction of the Giornale enciclopedico. ${ }^{2}$ This literary and philosophical periodical was published biweekly and sold in nineteen cities across the Italian peninsula and in Lugano. ${ }^{3}$ It offered its readers reviews, extracts, or announcements of the latest literary, scientific, philosophical, and historical works being published across Europe. It also supplied readers with information about the activities of local and foreign literary and scientific academies. In addition to providing Italian readers with direct access to new (Italian and Transalpine) ideas, the Giornale enciclopedico functioned as a discerning guide for readers who could afford to purchase books for themselves-a valuable service in the Veneto region of Italy, which during the eighteenth century boasted one of the richest book markets in Europe. ${ }^{4}$

As its title suggests, the Giornale enciclopedico drew inspiration from the French philosophes' great Enlightenment project, the Encyclopédie. In the flysheet announcing the upcoming changes in the periodical under her direction, Caminer explained that her goal was to "gather and present together diverse cognitions which, remaining scattered, would be largely unknown," and she underscored her belief that if "knowledge contributes to happiness," then her periodical, "a repertory of such cognitions ... a union of the diverse thoughts of cultured peoples," would be both useful and pleasurable to readers. ${ }^{5}$ Caminer recruited the most renowned men of letters and science from the Italian peninsula to contribute book reviews and essays to her periodical. ${ }^{6}$ In addition to writing her own original reviews, she published translations of reviews from French periodicals such as the Mercure de France and the Journal encyclopédique. She relied on these periodicals primarily to keep her readers informed about books to which she herself did not have access, but also to provide the Italian public with selections from foreign periodicals. Under her direction, the Giornale enciclopedico became the most progressive Enlightenment influence in the Veneto region of Italy: a "combative journal," as one scholar has described it, that challenged "the principle of authority ... on all fronts ... from theology to law, from literature to economy, from the slavish politics of the colonial powers to the arrogance of feudal lords and big landowners in the Veneto." 7

As one of Italy's first female journalists, ${ }^{8}$ Caminer enjoyed the privilege of participating in and monitoring contemporary debates on everything from the latest scientific experiments in regeneration, to capital punishment, to the status of the Italian language and literature. She also used her periodical to participate in the centuries-old querelle des femmes. Throughout the twenty-eight years of her career she published reviews and announcements of books by, for, and about women in her periodical. She commented on a wide range of issues: women and literature (as object and as author); childcare (whether or not mothers should nurse, or whether or not they should follow Lady Mary Montagu's suggestion of inoculating children against small pox); religion (forced vow-taking; power hierarchies within the clergy); marriage (dowries; the health and duties of women about to marry); social institutions (houses established by women to care for poor or orphaned children); women in Eastern or New World cultures as compared to those of Italy or Europe; women in history; women and education; and fashion publications for women. 
One of Caminer's most fervent convictions was that women had a right to a life of the mind. She chafed against what she called the "prejudice [that] would have women confined within unreasonable limits," and throughout her career she published reviews in which she held up as models the literary and scientific accomplishments of female intellectuals, both contemporary and historical. At the age of eighteen Caminer published a review in which she proclaimed openly that there was "no reason for us [women] to hide ourselves," that it was "most reasonable" for women to find satisfaction in seeing themselves "as good as men at everything." ${ }^{10}$ She inveighed against men who wished to "claim exclusively for themselves the right to teach in universities," despite the "good number of women who held posts and taught classes at the most celebrated universities," and she proudly described her female compatriots from Bologna, highlighting in particular "the most celebrated Madame Laura Bassi, who counts among her disciples many of the most renowned professors who came out of her school and joined the ranks of the most illustrious academies of Italy." 11 Thus the young Caminer not only advocated for women's right to receive a solid education, she championed their ability and their right to deliver an education as professionals from the university podium.

Caminer's convictions about women's intellectual capacities-and about her society's obstacles to the development of these capacities-were fundamental in shaping her opinions about the fashion periodicals for women that appeared for the first time in the last quarter of the eighteenth century. In the flysheet to the Giornale enciclopedico she informed readers that she would address the topic of fashion in the periodical because, she exclaimed, "Oh, how many times do fashions reveal the character of heads!" 12 But the first issue of the Giornale enciclopedico under her direction clearly indicates that if Caminer was interested in the way fashion "revealed" the character of individuals, she was also vitally concerned with its power to shape character and influence lives, especially for women. In the review mentioned above, Caminer issued a cautionary plea to her female readers. ${ }^{13}$ In what was clearly a personal digression from the book at hand, she warned them about the dangers so many women faced in choosing the toilette over the writing table-dangers she believed affected all women. She exhorted her peers to understand the irony and the peril of mistakenly believing that they were in a position of power over men:

\footnotetext{
It [is] . . . a consolation, for a woman especially, to be able to speak about a translation done by a member of that sex, which [while] courting men's injustice, seems to willingly renounce its own portion of talent and common sense in order to receive a frivolous exchange of apparent homages, ill-founded praises, dangerous adulations and futile bonds which keep us ever more bound in slavery even as we believe ourselves to be receiving tributes and as we go along proud of our empire. $^{14}$
}

Caminer's personal struggle with this issue as a member of "the fair sex" is evident in her oscillation between speaking of women as "that sex" (and "its" talents) and identifying herself as part of a collective group of women subjugated by men ("us," "we," "ourselves"). Her own accomplishments and her lifelong com- 
mitment to publicizing other women's literary, scientific, and philosophical contributions bear witness to her profound faith in women's innate capabilities and in their right to be considered the equals of men. Yet there is a sense in this passage that she felt betrayed by the majority of women who forfeited the development of their talents-or even the use of their common sense-in return for a false "empire" of superficial adulation offered to them by men. The direct consequence of such behavior was that it allowed men to retain their superior position in the gender hierarchy of society. The significance of such behavior, for Caminer, was that it made women complicit in their own subjugation. ${ }^{15}$

Caminer was writing during the second half of the eighteenth century when women in Europe were fast becoming an important new sector of readers (and writers) for the publishing industry. This burgeoning economic interest group was primarily composed of women from the aristocracy and the middle classes: women who were exceptionally educated; women who were moderately literate and had some leisure time; and women who were unable to read but had access to the texts because their family or friends read to them. Female readers came to be viewed as a new consumer group, and all over Europe there was an explosion of texts by, for, and about women: novels, etiquette manuals, moral tales for the education of young girls, scientific tracts adapted for women, essays on marriage and the duties of future brides, religious treatises, periodicals and almanacs, and catalogs of illustrious women. ${ }^{16}$ In an era when for the first time women had such a plethora of reading materials at their disposal, Caminer considered it both an opportunity and a responsibility for women to take advantage of the situation and to educate themselves wisely.

Among all the types of reading materials accessible to eighteenth-century women, fashion periodicals constituted a new genre. ${ }^{17}$ During the final quarter of the century fashion-plate series and full-fledged fashion periodicals came into their own for the first time, with Italy following England's and especially France's lead. ${ }^{18}$ Fashion plates-hand-colored prints of women and men attired in the latest clothing and accessories-were easily reprinted and inexpensively mailed, and they came to replace the exorbitantly expensive and exclusive fashion dolls (similar to modern-day mannequins) that were dressed in the latest clothing styles and shipped internationally from city to city and from court to court. ${ }^{19}$ Fashion periodicals incorporated the popular fashion plates into a new genre specifically dedicated to light reading for women on a variety of subjects, including beauty remedies and instructions on deportment and proper manners. This particular combination of the written word and iconographic fashion images was a powerful new force in promulgating ideas about masculine and feminine roles in society. ${ }^{20}$ One of the earliest examples of fashion periodicals which will concern us here was the immensely successful Cabinet des modes, compiled by Jean Antoine Lebrun in Paris. It was founded in 1785 and continued with two title changes until it ceased publication in 1792. ${ }^{21}$ One testament to the Cabinet des modes's widespread popularity is that it was copied in England, Germany, and, as we shall see, Italy.

Fashion periodicals were easily available to the upper and middle classes by subscription, and they contributed immensely to what fashion historians have described as a democratization of fashion. ${ }^{22}$ The illustrations included in each 
issue allowed illiterate members of society to appreciate the wares the periodicals were advertising, and servants could easily gain access to the periodicals through their masters. ${ }^{23}$ Sometimes the periodicals provided names of manufacturers and merchants from whom readers could purchase featured items. In advertising the fashion industry's wares, fashion periodicals functioned as ambassadors of sorts, exposing readers to international clothing trends and encouraging them to purchase luxury goods (whether imported originals or domestic imitations).

But fashion periodicals had another important function: that of defining and reflecting social status and discerning good taste. ${ }^{24}$ Over time the textual component of fashion periodicals increased, and the periodicals began to function more and more as conduct manuals as well as fashion references. Aside from dictating proper attire for a variety of social situations, they offered advice on moral dilemmas, courting rituals, marital concerns, and other aspects of contemporary social life. Indeed fashion "became a means of social arbitration whose authority challenged the claims of those traditional arbiters of mores and manners: the Church, the State, the Academy, and the Republic of Letters." ${ }^{25}$ As a writer who earned a living in the difficult business of producing a periodical, Caminer might have been inclined to sympathize with the new fashion periodicals. But her role as an intellectual woman working to counteract anything that celebrated female frivolity ultimately placed her in direct opposition to them.

Caminer was not opposed to the fashion industry per se, however. She almost certainly recognized fashion's potential business and trade benefits, regardless of what she perceived to be its inane nature. Indeed, her comments in the Giornale enciclopedico reveal her appreciation of fashion as an industry with its rightful place in the world of commerce. In one of her earliest commentaries on the subject, published in 1778, she defined fashion [la moda] as follows:

Fashion, a futile matter in itself, but which is an essential part of luxury and of interest to commerce, takes on various modifications according to nations and to individuals. It is impressive because of the number of its devotees. It occupies the mind and distracts the heart, it affects customs no less than clothes, and it increases the means of our subservience to the French. ${ }^{26}$

The passage illustrates Caminer's understanding of the powerful and multifaceted influence of the fashion industry on the world around her. Even as she noted fashion's capacity to act as a monitor of social behavior in addition to habits of dress, she did not offer a condemnation of luxury or its evils, as did many of her contemporaries. She merely registered the fact that an impressive number of people were held captive under fashion's sway, despite the obvious uselessness (in her view) of trying to keep up with constantly changing trends. The only critical aspect that stands out in this passage is Caminer's chagrin over Italy's obsession with current French fashions. To her mind, this preoccupation served only to further increase Italy's cultural subservience to its northern neighbor. ${ }^{27}$

Caminer's critique of fashion periodicals is interesting precisely because she did not voice many of the complaints that were lodged against the fashion industry by her contemporaries. She did not share the views of religious critics, for example, who complained that exorbitant desires for fashionable consumer 
goods fostered greed and immodesty and led to the sins of "worldliness, vanity, envy and lack of charity." ${ }^{28}$ Nor did she share the extremely common fear that the fashion industry threatened to undermine the visible (sartorial) distinctions between classes. ${ }^{29}$ Even Caminer's views about the fashion industry's deleterious effects on women were different from those expressed by the majority of her contemporaries. The most prevalent lament was that women who spent too much time and money on their clothing neglected their domestic duties, brought their families into debt, and inevitably fell into general moral corruption..$^{30}$ In contrast, Caminer was concerned about the way the fashion industry-and in particular its periodicals-helped maintain and reinforce the gendered hierarchy of her society. As evidenced in her opposition of the toilette to the writing table, Caminer believed that women's preoccupation with their outward appearance led them to neglect the development of their minds. For Caminer-who was herself breaking the intellectual gender boundaries of her society-this meant that women would never be considered the intellectual equals of men, and it exposed women's complicity in their own subjugation.

Despite her initial and decidedly unhostile definition of la moda, then, Caminer came to be wary of the fashion periodical's power to proscribe-not just describe-the interests of a female audience. In this article I will focus on a series of reviews that Caminer published in her periodical between 1777 and 1786 to illustrate how and why she became a vehement critic of fashion periodicals. As we shall see, four factors contributed to the radical change in her opinion over the course of ten years: the increasing popularity of fashion periodicals; their successful arrival in Italy; the shift in their focus from advertising luxury items (for both women and men) to constructing a forum for the moral and intellectual education of women; and finally, what Caminer perceived as increasing complicity on the part of Italian women as they went from being "unwitting" followers of fashion trends to acting as editors of the periodicals themselves.

In the April 1777 issue of the Giornale enciclopedico, Caminer published her first review dedicated specifically to a fashion publication: the new fashion supplement to the Gazzetta toscana. ${ }^{31}$ The special status she accorded the review is evident in her unusual decision to create a separate column for the review, entitled simply, Moda. She sent an advance copy of her essay to a colleague, telling him that her review was designed to "provoke laughter" and to demonstrate that "everything in the world is a contradiction, since France offers us more striking examples of futility at the same time as it makes us envy its great men." 32 In the review, she described the Gazzetta toscana's plan to publish fashion plates depicting female and male figures in both everyday attire and court dress. She commented wryly that the fashion prints in this twice-monthly publication would include "all the most exact accessories, from the hair at its roots all the way to the tips of the shoes inclusively, according to the various styles that the dictators of the century pass as law every quarter of an hour." ${ }^{33}$ Although the review was clearly written in a humorous vein, the Enlightenment thinker's use of the phrase "dictators of the century" called attention to the tyrannical nature of fashion. Her facetious comment about the great mutability of French trends echoes Montesquieu's comment some fifty years earlier in his Persian Letters: “A woman who leaves Paris to spend six months in the country comes back as out of date as if she 
had been buried there for thirty years." ${ }^{34}$ Despite the obvious exaggeration of Montesquieu's comment, Caminer's own hyperbolic account actually suggests a quickening in the pace of French fashion trend-setting by 1777.

It seems that Caminer was at this point a willing, if bemused, participant in reviewing - and therefore publicizing - this fashion project. She even remarked ironically that the Florentine fashion supplement "will be good for our newspaper as well, whose merit will be indisputable if it can often report such important news." Caminer was able to jest openly with her readers in this tone because she was confident that they would share her discerning view of the "Dictatorship of Fashion." This is perhaps most obvious in her airy pronouncement of the periodical as a "happy victory" for women:

\begin{abstract}
Victory, happiness for our sex, and for that part of the other sex which knows its own interests well enough not to put on excessive airs by disparaging lovable, womanish futilities. The lords of creation, in fact, have descended towards their most humble handmaids so that, almost universally having become elegant baubles along with the women, they do not leave them in the dregs, not even in matters of appearance. ${ }^{35}$
\end{abstract}

Caminer undoubtedly imagined that her readers-especially her female readers, whom she regarded as the primary dupes of la moda-would be as amused as she was that men, too, were caught up in fashion's sway. ${ }^{36}$ She even described the way fashion had encouraged a sort of leveling of the hierarchical relationship between the male "lords of creation" and their "humble handmaids."

Caminer underscored the financial aspect of the Gazzetta toscana's fashion supplement, whose success was inseparable from its commercial power: she declared ironically that the periodical would proffer a great number of wondrous items to its readers "for a sum which would be considerable perhaps in other cases, but which is very small for the matter at hand." ${ }^{37}$ In the conclusion to her review, Caminer presented her readers with a clear-eyed assessment of whose interests the fashion periodical served, and in what ways it would do so: "This happy enterprise will begin in May; it will distract men and give them relief from ponderous thoughts and administer new means for women to continue their open or secret rule over men. It will make the Florentine booksellers rich . . " ${ }^{38}$ In an echo of her earlier description of women's false "empire" over men, Caminer emphasized the ironic contradiction between the notion of women appearing to be in charge (as "open or secret" rulers of men) and the reality that they were merely helping to line the pockets of the men selling this publication.

Caminer also described the Florentine fashion supplement as evidence of France's successful duping of Italians. In its efforts to imitate French fashion consciousness, "Italy's genius" was "sharpening its wits" and "shaking itself from the sleep that was making it sluggish." ${ }^{39}$ To press her point, Caminer presented her readers with a farcical image of "ecstatic" Italians mincing in front of the French fashion mirror and reassuring themselves of their superiority with appeals to their own nation's great past:

Already everyone easily understands the French, who, in a strange contradiction, offer a bizarre contrast of solidity and superficiality: they perfect the sciences, expand the arts, torment themselves over fashion, 
and produce-if not with equal merit with equal fortune-great men and foppish dandies. They inspire undiscerning admiration on the part of ecstatic Italians, who, while copying the latter [dandies] and expressing admiration for the former [great men], console themselves as they ape gestures and movements in front of the mirror for being in the final end their masters from the beginning. ${ }^{40}$

Caminer's concern over her nation's misguided response to French authority in the fashion world would have been striking to her readers, because it was well known that she believed Italians were truly indebted to the French on many intellectual and cultural levels. With her cryptic phrase about her compatriots "consoling themselves" that they had been "masters" over the French "from the beginning" 41 - even as they practiced French gestures before the mirror-Caminer exposed her compatriots' complicity in their current subjugation to the French. Such complicity recalls Caminer's description of women's embrace of the toilette rather than the writing table. Indeed, between 1777 and 1778 she offered her readers twin images of subjugation (men's subjugation of women; France's subjugation of Italy) and self-delusion (on the part of women who believed themselves to be "open or secret" rulers of men; on the part of Italians who believed themselves to be the "original masters" of the French).

Still, in this review, Caminer was treating the topic of fashion in a lighthearted vein. She even placed a "virtual boutique" of the latest clothing and accessories at the center of her review, creating a lavish visual effect for her readers:

Colors, galloons, ${ }^{42}$ bonnets, embroidery, mantillas, ${ }^{43}$ cravats, laces, little purses, fans, small hats, big hats, hoops, no hoops, feathers, no feathers, wide and narrow dresses, low waistlines and high waistlines, hairstyles of every kind, all will be expressed, elucidated with proper explanations and opportune notes. And men will know if they should attend to their affairs with collars of many or few layers, ${ }^{44}$ with a minuet step or with an English air. ${ }^{45}$ Women will know if they can manage their families better with great or small circumference in their dress, and at what braccio italiano ${ }^{46}$ the height of their coiffure should correspond. ${ }^{47}$

In an engaging and mockingly playful tone, the journalist practically engulfed her readers in a mountain of clothing and accessories. In doing so, she replicated the overwhelmingly frivolous nature of the fashion world. She also highlighted some of the issues most discussed by contemporaries in regard to the latest fashion trends. The great heights of women's coiffures, for example, was the subject of many a caricature during the eighteenth century. Women's hair was piled high atop their heads, supplemented with pads or false hair (toupés), and often secured with pomatum. Their coiffures were laden with ornaments of all kinds-flowers, feathers, jewels, even bird nests, sailing ships, and other large objects. Reaching heights that often greatly exceeded the length of the face, women's hairstyles made passage through doorways and into and out of carriages difficult (fig. 1). ${ }^{48}$

The circumference of women's dresses was another common subject of debate. Women had a difficult time fitting inside carriages or slipping gracefully into seats at the theater. Sometimes the width of their petticoats forced them to pass through doorways by walking sideways. Women were also accused of taking up too much room when they were walking in the streets, making it difficult for 


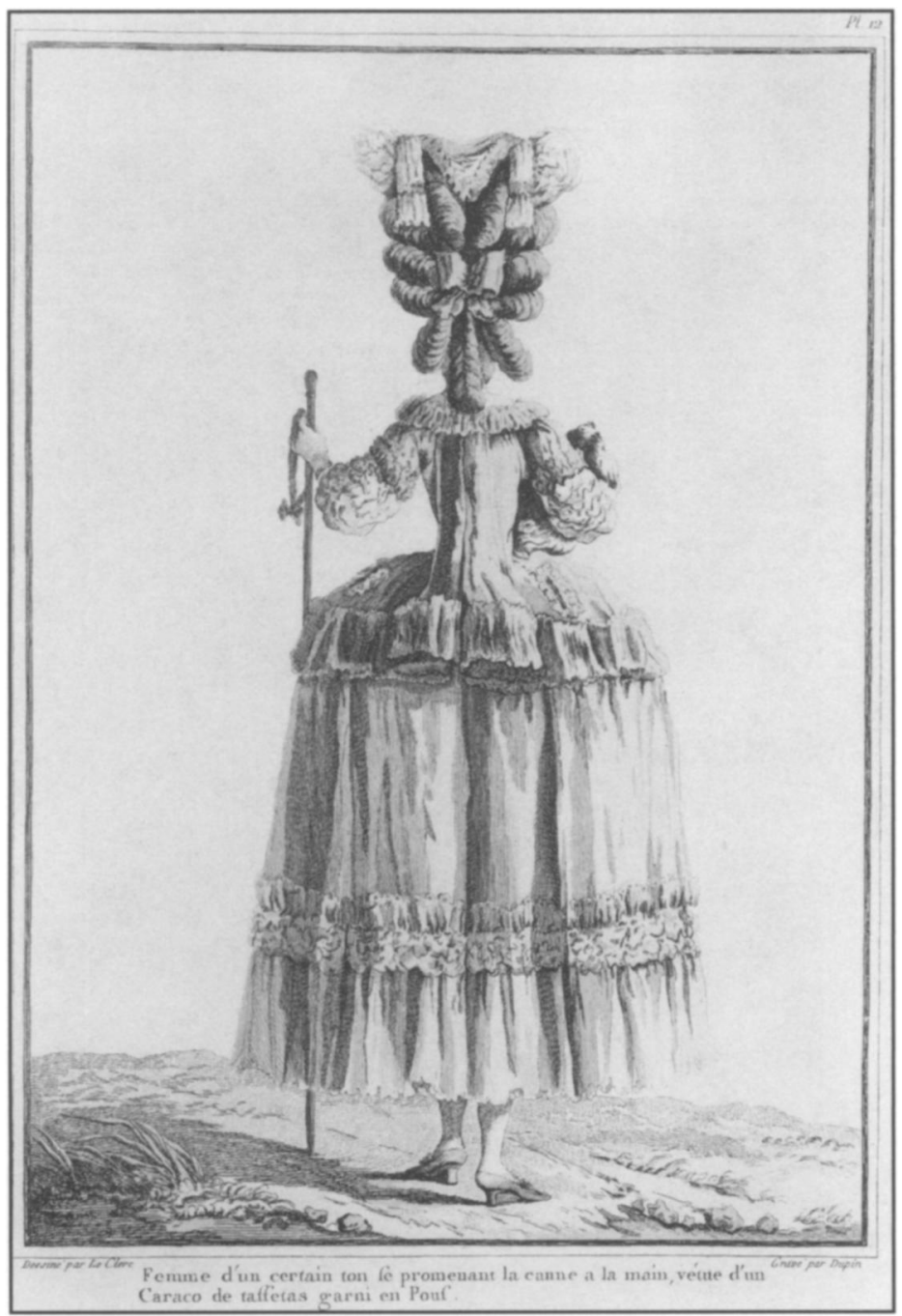

Figure 1. Femme d'un certain ton se promenant la canne à la main, vêtue d'un Caraco de taffetas garni en Pouf, from Galeries de Modes et Costumes français, 12 vols. (1778-1787), vol. 1, PL. 12. The Metropolitan Museum of Art, Irene Lewisohn Costume Reference Library.

other pedestrians or even for carriages to pass. This problem must have been particularly significant in Caminer's native city of Venice, where women were stepping in and out of bobbing gondolas and walking along the extremely narrow and maze-like alleyways of the city.

But what of Caminer's own complicity in the pleasures of fashion? Her detailed knowledge of the fashion lexicon and her playful handling of it in this review suggest a certain fascination on her part with the topic. Certainly her presentation of the "virtual boutique" implicated her in helping to advertise the latest wares fashion periodicals were selling. For some evidence that she was not immune to the draw, demands, or pleasures of the fashion industry, we may turn to the sole surviving portrait of her (fig. 2). ${ }^{49}$ The portrait depicts her in a Turkishstyle dress with a pleated double ruffle-the height of fashionable wear for European women in the late 1770 s and early 1780 s (fig. 3). In accordance with current 


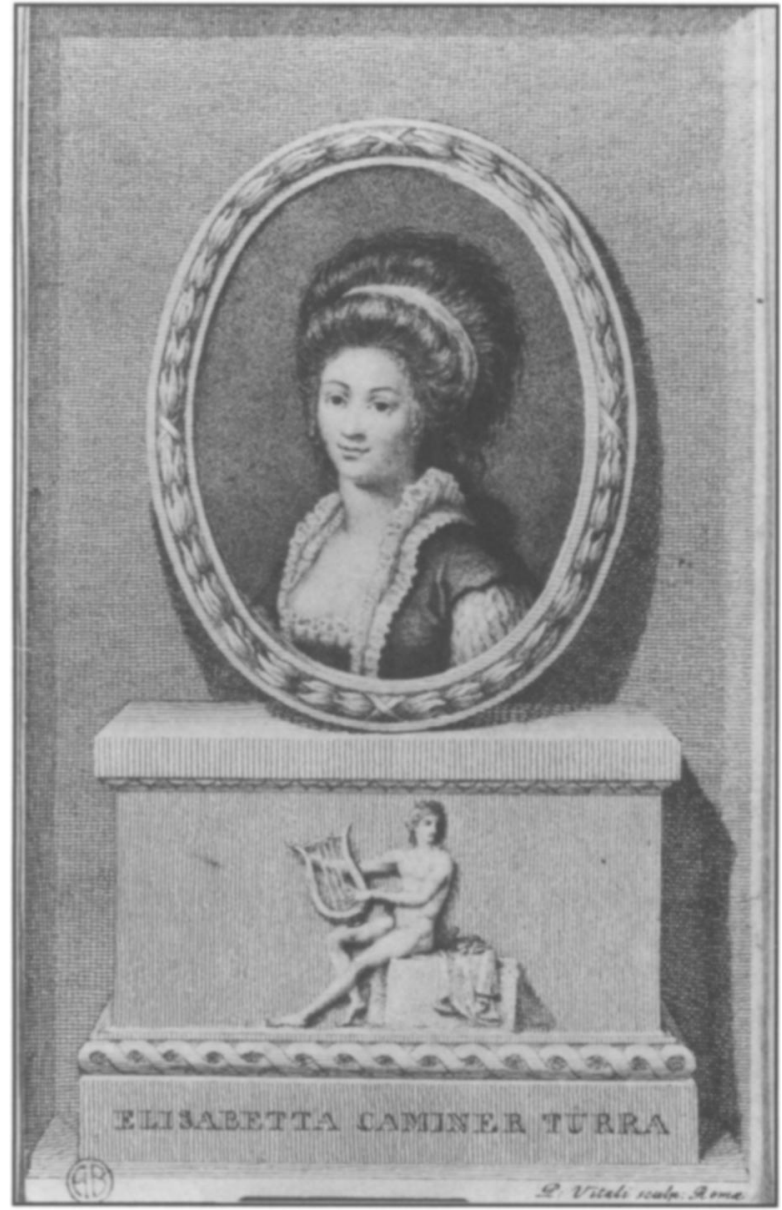

Figure 2. Portrait of Elisabetta Caminer Turra. Civica Raccolta delle Stampe “Achille Bertarelli," Castello Sforzesco.

practices, Caminer had undoubtedly placed a toupé or hair pad under her own hair in order to create a more voluminous effect. Of course, we cannot know whether these styles represent what she really wore from day to day or whether it was the painter's decision to portray her this way, as was often the custom for portraitists. But whether or not these were her own clothes or her usual coiffure, the fact that she wanted to or agreed to have herself portrayed this way is significant for our discussion. Her reputation as a beautiful woman could only have been affirmed by a show of her "literacy" in the latest fashion trends. She might also have used a fashionable, feminine portrait such as this to help mitigate contemporary uneasiness about the intellectual boundaries that she was breaking with her "masculine" profession. Despite the apparent contradiction with Caminer's general philosophy of opposing the writing table to the toilette, it would undoubtedly have made good business sense for her to promote such a fashionsavvy image of herself. ${ }^{50}$

To a certain extent, then, Caminer acknowledged-implicitly and explicitly-her participation in the pleasures of fashion. But as a letter to her Florentine colleague Giuseppe Pelli Bencivenni suggests, she made an important distinction 


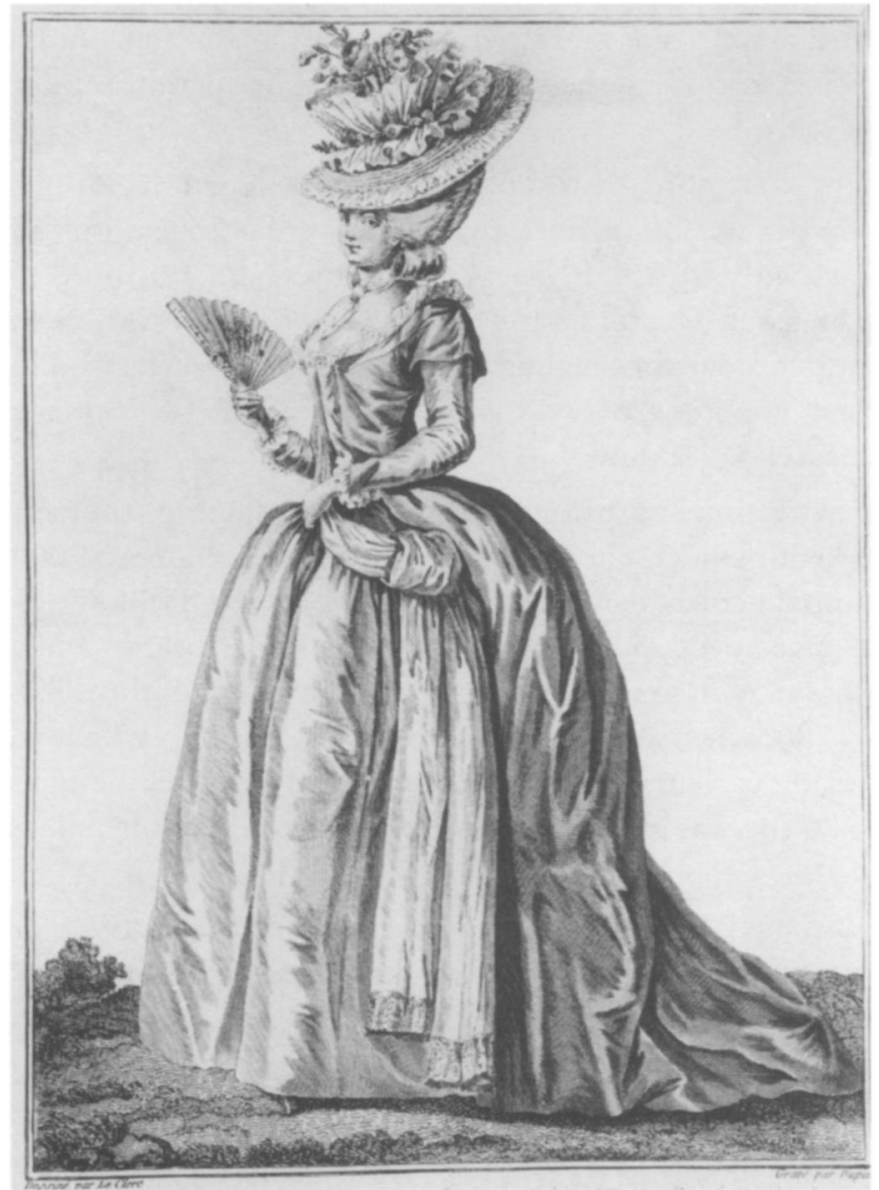

Figure 3. Robe à la turque (1780), from Galeries de Modes et Costumes français, 12 vols. (17781787), vol. 2, PL. 130. The Metropolitan Museum of Art, Irene Lewisohn Costume Reference Library.

in terms of where her own toilette fit into her life priorities. Or, at the very least, she was careful to articulate this distinction when portraying herself to her contemporaries. Her reputation as a beautiful woman who was also considered an intellectual exception to her sex made her the source of much curiosity on the part of her male colleagues. In response to what must have been Pelli's query about some aspect of her toilette, she wrote:

You grant me even the time for adorning myself; but in order to [have time to] write to my friends, I do not make it a necessity for myself. Whether I consider myself beautiful or ugly, if ugly, in vain would I hope to make up for nature's defects with art; if I am not ugly at all, I am pleased because even this can be an advantage.... Do not think, however, that I have one of those philosophies that I call rude. No, one must live and embrace neatness, but not sacrifice to this the time owed to friendship. ${ }^{51}$

Caminer opposed time for "adorning herself" with time for writing to friends. It is essential to note that her correspondence was a fundamental part of her profession and a primary means for her active participation in the Republic of Letters. ${ }^{52}$ 
In her case, writing to friends meant writing to the most prominent Italian men of letters and science, recruiting their participation in her periodical, or exchanging books and book reviews.

Perhaps even more interesting is the rare comment regarding her perception of her own beauty. She claimed that if she were not beautiful, she could not change that fact with artifice. If she were beautiful, she welcomed the notion of her beauty as an asset. The riddle-like structure of her observation was undoubtedly a deliberate strategy for tangling with this delicate subject by allowing her to avoid appearing immodest, the way a direct admission of enjoyment of her own beauty would surely have done.

In 1777, Caminer's attitude towards the fashion phenomenon was primarily one of bemusement. She even seems to have been amused that her role as journalist required her to "participate" in the business of fashion to some extent. As we shall see, however, the cautions she raised to her peers-and especially to the members of her own sex-would become paramount in the radical change in her views by 1786 , when she published the two reviews to which we now turn. Whereas a decade earlier Caminer had published a review designed to amuse readers, by 1786 she was engaged in a veritable war against fashion's designs on women.

By 1786 the Parisian fashion periodical, the Cabinet des modes, was enjoying international popularity. ${ }^{53}$ In only its second year of existence, its title changed to the Magasin des Modes nouvelles françaises et anglaises, further reflecting the international power of the fashion industry. Like their English and German counterparts, Italians embraced the Cabinet des Modes by reproducing their own versions of it in their native land. ${ }^{54}$ One of these imitations, the Giornale delle dame e delle mode di Francia (Periodical of the Ladies and Fashions of France), was produced in Milan, the other, La donna galante ed erudita. Giornale dedicato al bel sesso (The Gallant and Learned Woman. Journal Dedicated to the Fair Sex), in Venice. ${ }^{55}$ Both periodicals reproduced fashion plates directly from the Cabinet des modes, and they also presented readers with translated versions of the French periodical's reading fare. The Italian periodicals contained original material as well, especially in terms of their reports on local theatrical and literary events. ${ }^{56}$

Caminer's review of the Milanese Giornale delle dame e delle mode di Francia appeared in the May 1786 issue of the Nuovo giornale enciclopedico. ${ }^{57}$ She placed the review in the bibliographical section of her periodical, which was dedicated to listing new and forthcoming publications. In this section of the periodical Caminer and her collaborators usually limited their descriptions of new publications to a few sentences. In this case, however, Caminer took the unusual step of writing a full-length review, ${ }^{58}$ thereby echoing the structural change she had implemented in 1777 for the review of the Florentine fashion periodical (that is, creating a special column for that one issue).

An interesting stylistic parallel between this review and the 1777 review illustrates how Caminer's critique of fashion periodicals had evolved. Whereas in the earlier review Caminer had included a "virtual boutique" of fashion accessories, here she provided her readers with a "virtual library" of sorts, since the manifesto for this periodical explicitly stated its goal to "educate" women and 
attend to their "moral welfare." Caminer inundated her readers with a list of the insipid materials with which the Giornale delle dame proposed to "straighten out women's heads":

The manifesto for a Journal of the Ladies and Fashions of France was published in Milan, objects [ladies and fashions] that go together naturally, as everyone can see. This publication will embrace moral and delightful novellas, sensitive little novels, gracious short stories in translation and in the original, and these lovely things in order to procure the moral well-being of women. There is more. Instructions for the fair sex, in which matters of virtue will be linked together with matters of the toilette. One would think that these two things clashed with each other, but it must not be so. Also: poems, which the person who wrote the manifesto defines as the poetic part, in order to begin educating the fair sex. These are supposed to enliven the hearts of women, as in those [poems] that will be amorous, humorous and bizarre, and in order that they might enliven women's hearts in a healthy way, the sacred, the philosophical, and the tedious-which as we know are all one thing-will be eliminated. Also: gallant varieties, which is to say literature, music, painting, anecdotes, and witty puns that will be delineated in a bizarre way. Also: current French fashions, an article that is declared the most interesting; and here there will be engravings, descriptions, and all that can contribute to straightening out women's heads. ${ }^{59}$

This time Caminer did not present her readers with a simple list or inventory, as she had done in the earlier review. Within the body of items in this "virtual library," she inserted a running critique of the materials condoned by the fashion periodical as ideal for women's education. In doing so, she underscored how silly and superficial subjects were promoted: even when serious topics were mentioned (literature, music, painting), the editor blatantly undermined them by declaring that they would be presented in a "bizarre" way. Caminer also criticized the manifesto's automatic coupling of "virtue" with the "toilette." And, significantly, she protested the manifesto's implication that "ladies" and "fashion" were "objects" of equal status.

She continued her critique by recalling the poor state of women's education and sarcastically related the fashion periodical's promises to ameliorate it: "We were complaining, poor women, that our education was neglected: the Heavens have provided for us, too! Good parents, in what a happy age our daughters are born! With twenty-four lire a year you will protect them from boredom and from awkwardness, and you will shape their minds and hearts." ${ }^{60}$ Addressing readers who were parents of young girls, she reminded them that the publishers of this fashion periodical would actually have them pay to provide their daughters with such a form of "mis-education." At this point, it seems that Caminer could no longer refrain from showing her anger, and she laid down the sarcastic mask covering her authentic feelings: "We were able to jest until this point; but upon reaching the following passage from the incredible manifesto, we cannot hide our reasonable indignation. Glance at it, readers, and whoever wants this wise periodical afterwards, grab it." ${ }^{61}$ In the 1777 review, she had been confident of her readers' critical eye towards fashion periodicals. Now she was confident of 
just the opposite phenomenon: she knew that some readers would buy the publication regardless of its self-evident worthlessness. In a gesture akin to throwing up her hands in bewilderment, she let the "incredible" manifesto to the forthcoming Giornale delle dame speak for itself as she quoted a passage directly from it:

'In this way, this periodical being to be the triumph of Italian ladies, one does not despair of a gracious welcome from them and from the friends of this most respectable sex. In a work consecrated to women's pastimes, it will be easy for another woman to find a way to distinguish herself: she desires to mask what is useful with what is pleasing, and it must be a truly good fortune to be able to say she is preparing an idleness for them that could enchant their minds, leave some trace in the depth of their hearts, and likewise give real value to a momentary distraction. Dedicated to the Graces, this work will not even be deprived of that tone of indulgence that characterizes it. This way, any criticisms that arise will be disarmed. ... And the principal goal of this work will always be to instruct the fair sex with pleasantness and with gallantry. ${ }^{, 62}$

Caminer was confounded that the manifesto boasted about the insipidness of the periodical-as if the Giornale delle dame did not aim to be taken seriously, despite its claim to be "the triumph of Italian Ladies." According to the manifesto, the periodical's very emptiness would render it popular with both "gracious" women and their male friends. The manifesto even revealed that the Giornale delle dame's lack of real substance had the important strategic purpose of rendering the periodical immune to serious criticism. Indeed, it seems that even Caminer was at a loss for words here.

The passage from the manifesto celebrated the very notion that Caminer found so reprehensible: that women's education should be happily relegated to the superficial. The Giornale delle dame's goal was not to combine the useful and the pleasurable in order to instruct and delight (according to classic Enlightenment philosophy), but rather to mask any usefulness with pleasurable things. Rather than encouraging women to pursue experiences of real growth and worth, the periodical promised to affix a "real value" to what was really only "a momentary distraction." 63

By 1786 Caminer understood that the fashion periodical was becoming a new forum for defining and redefining women's place in society-indeed for manipulating the notion of "femininity" itself. As scholar Rebecca Messbarger posits in her study of fashion periodicals, "the woman's magazine proffered a new species of literary discourse.... An unorthodox subset of the conduct manual, it schooled women in the art of self-production and endless reproduction. . . . [It] represented to its readers multiple, often discrepant, ideal images of themselves, which they were to emulate if they wished to enter le monde." ${ }^{64}$ Messbarger argues effectively that the fashion periodical encouraged women to "[simulate] the prevailing feminine ideals in their dress and conduct" as an essential strategy for enhancing their power and prestige. ${ }^{65}$ This ideology was completely at odds with Caminer's agenda to reject those ideals and expose them as stereotypes detrimental to women's status in the world. For her, if women were ever to obtain the rights to them, Liberty and Equality could not be companions of Frivolity. ${ }^{66}$ 
Caminer was indignant about the Giornale delle dame's ideology, its content, its implications for the condition of women's education and its certain popularity. The hardest blow for this protofeminist, however, was the idea that a woman edited the Giornale: "To top it all off, it seems that the author of this periodical is a woman. Were we not treated with enough disdain by men without reducing ourselves to the humiliation of showing ourselves to be contemptible?" 67 Since scholars today do not know the identity of the Giornale delle dame's editor, this passage is especially interesting. ${ }^{68}$ Perhaps Caminer's review introduces new historical information. But even if the editor was not a woman as Caminer suspected, it is significant that the very possibility of a woman at the helm of such a publication shocked and disturbed her. From her point of view, the fashion industry-in addition to encouraging insipid behavior in women-had successfully inspired women to participate as leaders in its success.

For Caminer the significance of such a fact would have been twofold. First, since they were playing leading roles in an industry which institutionalized the "lovable womanish futilities" she had written about facetiously a decade earlier, contemporary women were actually becoming more complicit in their subjugation to men (going from unwitting followers to misguided leaders). Second, women's leadership role in publishing fashion periodicals helped to legitimize such stereotypically "feminine" behavior in a powerful way. Caminer's sarcasm and especially her open expression of indignation and humiliation clearly reflect her anxiety about fashion's ability to undermine intellectual accomplishments women were making, or might make in the future. ${ }^{69}$ To make matters worse, the Milanese editor of the Giornale delle dame may have been the first Italian woman to edit a fashion periodical, thereby bringing the treacherous phenomenon ever closer to home for Caminer.

How, then, would she confront the delicate situation of reviewing a $\mathrm{Ve}$ netian fashion periodical for women? What if the editor of such a publication identified closely with Caminer's family and occasionally and favorably reviewed her father's and her own work in the periodical's pages? Just such a situation occurred when the manifesto for the forthcoming Donna galante ed erudita was published later that same year. Scholars believe that the anonymous editor of the periodical was Gioseffa Cornoldi Caminer, Elisabetta's sister-in-law.

Two months after her review of the Giornale delle dame, Caminer announced the new Venetian periodical. Clearly, she would not have wanted to blatantly offend her sister-in-law or taint her family's journalistic reputation in any way. She therefore wrote the review so that a superficial reading of it might not reveal all the complexity of her ironic and disapproving subtext. Nevertheless, attentive readers would not have missed her inherent critique of the periodical. Just as she had done in her review of the Giornale delle dame, Caminer made a point of describing the Donna galante ed erudita using the very discourse of the fashion genre, using exact words and phrases contained in the periodical itself:

A capricious manifesto published in Venice by the Albrizzi bookshop ... promises for the first week of September the first issue of a new periodical entitled The Gallant and Learned Woman, written à la mode, that is to say, without the chaff [crusca], and with the glorious liberty that reigns among writers of bon ton. ${ }^{70}$ 
Her use of the word "capricious" here is double edged. Depending upon her readers' support or criticism of fashion periodicals in general, they could have interpreted it negatively, to mean "frivolous" or positively, to mean "whimsical." In the same way, the phrases "à la mode" and "bon ton" might have been viewed with a critical or an approving eye.

The expression "without the chaff [crusca]" is particularly significant here. It alludes to the conservative Florentine Accademia della Crusca, founded in 1582, which was dedicated to defending the "purity" of the Italian languagethe hegemony of the Florentine dialect and the literary models of Dante, Petrarch, and Boccaccio-against "invasion" by other dialectal or foreign words (thereby separating the seed from the chaff). In the context of the Enlightenment linguistic debate, Elisabetta Caminer and her father rejected the traditional, Crusca-oriented approach and favored clarity and simplicity of style over scholastic formality, especially for the language of periodicals. ${ }^{71}$ They joined other progressive thinkers in favor of expanding the Italian language through the use of other dialects and especially through the adoption of foreign words or neologisms, thereby giving it the elasticity to clearly and accurately express new ideas.

In the Donna galante ed erudita, Gioseffa Cornoldi, too, rejected the constraints of the traditional "crusca" ideology, but on rather different grounds and with a different goal in mind. Whereas her sister-in-law's purpose was to free scientists, philosophers, and all men and women of letters to use language as a tool for spreading knowledge in the most effective way possible, for Cornoldi it meant rejecting the use of a "masculine" language which was "inappropriate" for women writers and readers. In her apology [giustificazione] in the first issue of the Donna galante ed erudita, Cornoldi claimed to be writing "in a new way" that was suitable for "feminine literature," the genre to which she acknowledged she must "limit herself." 72

In her study of the Donna galante ed erudita, Messbarger describes how Cornoldi set up a direct opposition between the "crusca"-as a metaphor for the stiff, weighty, "masculine" language associated with the Accademia della Cruscaand "polvere di cipri," a silky dusting of Cyprian cosmetic powder which "must be" applied liberally to women's heads, face, and hands-as a metaphor for the type of light reading which she deemed ideal for women. ${ }^{73}$ Messbarger's skillful analysis of Cornoldi's ideology argues that for Cornoldi, the fashion periodical was a new, legitimized space where women could "exploit their subordinate status in order to attain their desired ends rather than to challenge overtly their subjugation to men and to established gender roles." 74

In her role as the editor of a fashion periodical for women, Gioseffa Cornoldi confounded her sister-in-law's “writing table-vs.-toilette” paradigm. She was not a woman rejecting a career at the writing table in favor of endless hours at her toilette. Rather, she was merging the two things and helping to create a new model of femininity that was based on what Caminer must have considered to be the worst in misguided frivolity and duplicity. ${ }^{75}$ In contrast to Cornoldi's view that her fashion periodical represented a separate literary sphere where women could (and should) assert their authority, Caminer must have seen her sister-in-law and the Donna galante ed erudita as complicit in helping to "make dolls of women."76 
The contrast between the two sisters-in-law embodies two very different models of women readers and writers coming to the fore in the last decades of the eighteenth century. Caminer's goal was to prove that women were as capable as men of intellectual development: if they were allowed a proper education, women could read (and write) the same, erudite material as could men. In contrast, Cornoldi preferred to embrace a genre that was explicitly for women: frivolous and contradictory as fashion periodicals might be, they could also be promoted as exclusively written-and controlled-by women. If Cornoldi believed she was helping to promote a genre that was "separate but equal" to other genres that were more suitable for men, Caminer was convinced that this conclusion would only help solidify the "separate and unequal" balance of power between men and women. ${ }^{77}$

The rest of Caminer's review of the Donna galante ed erudita makes her grim conclusion quite clear. As in earlier reviews, Caminer reproduced the list of articles that were slated to appear in the first issues of the Donna galante. Significantly, she introduced the list by explaining that the editor of the fashion periodical had included the titles in the manifesto in order to "entice women, who are meant to be the principal owners of this periodical." In highlighting the intended "purchase power" of the list, Caminer presented the Donna galante ed erudita's goal as what we might term a commodification of women's education:

Tales that are not moral. The first is: What to do? -A Sweeping
Criticism of Cavalieri Serventi-Ways to Conserve Women's Beauty-
Thirty Things (Preferably Joined Together) That Make a Woman
Perfect-What Is the Most Likely Quality to Make a Marriage Happy?...
Erudition: Weddings of the Ancient Romans-Apology of Modern
Marriages-New Books That are Suitable for the Female Sex ... ${ }^{78}$

In presenting her readers with this list, Caminer undoubtedly wished to highlight the absurd and contradictory nature of the periodical's contents. It goes without saying that the periodical's focus on beauty remedies, artifice, courtship and marriage, and limited reading for women ran counter to Caminer's idea of what constituted ideal reading materials for women.

Perhaps the most striking aspect of Caminer's review was her concluding remark, which acknowledged that women would rush to subscribe to this periodical: "Ladies will so easily find what they need in this periodical," she wrote, "that it will be hard for them not to compete at increasing the number of its subscribers." 79 The comment reflects an increasing realization on her part that fashion periodicals were conquering the market of female readers. ${ }^{80}$ She knew women would subscribe in great numbers because by then women readers-and even women writers-were entirely implicated in this cultural construction of femininity. ${ }^{81}$ She was forced to admit that women now irrevocably saw themselves through the looking glass of fashion.

Caminer's comment also raises the question of competition between periodicals like the Donna galante ed erudita and the Giornale delle dame e delle mode di Francia with her own Nuovo giornale enciclopedico (figs. 4, 5, 6). Could she (and other women writers like her) successfully compete with such a popular source of diversion for women? Which model would prevail-light, entertaining 

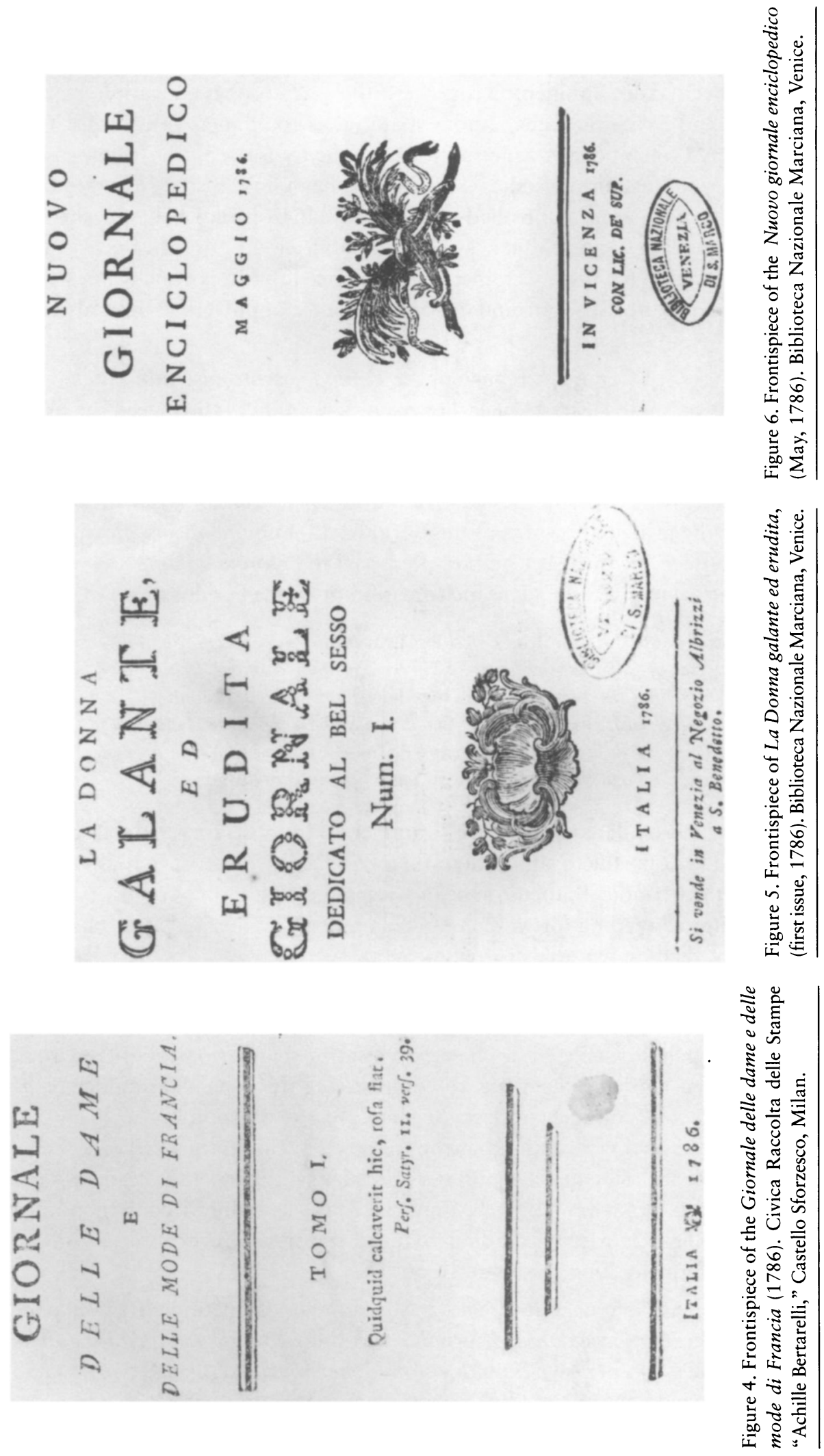
fare for women or instructive reading for all who sought to develop their minds? Would the majority of female readers succumb to the pleasures of fashion periodicals and openly celebrate separate and well-proscribed spheres for women and men? By the time Caminer published this review, she had gone from viewing fashion as a "futile matter of interest to commerce" to recognizing it as an overwhelmingly powerful force in shaping the gendered boundaries of her society.

Caminer was not alone in her perception of fashion's perils. Six years later, her English contemporary Mary Wollestonecraft would also describe a preoccupation with fashion as a "badge of slavery" in her Vindication of the Rights of Woman. ${ }^{82}$ But by 1792 when Caminer reviewed the Vindication in her periodical, she could only look to Wollestonecraft's (and her own) lofty goals for women as impossible to realize: "This woman is the champion of her sex. But what will she gain? Revolutions are not so easy or frequent in all genres." ${ }^{83}$ Caminer's terse comment implied that the French Revolution had been more easily instigated than a revolution for women's rights ever would be-and not least because of women's own complicity in their lot. Such was the resignation of a woman witnessing her peers voluntarily choose to become subjects under the Dictatorship of Fashion rather than citizens in the Republic of Letters.

\section{NOTES}

1. Giornale enciclopedico (January 1777): 80. "Ell'ha appresa una lingua straniera, conosce l'uso della penna, sa star seduta ad un tavolino piuttosto che a una toeletta: ell'eccita in conseguenza un desiderio che rade volte suole aver per oggetto una donna, quello di vederla rendersi utile alla sua Nazione maneggiando dell'Opere che possano procurarle dei vantaggi reali o dei piaceri. . ." (All translations from the original Italian into English are my own.) Caminer was reviewing the Compendio della storia e della morale dell'antico testamento, con spiegazioni e riflessi (Vicenza: Veronese, 1777), an Italian translation of the original work by François Philippe Mezanguy. The catalog of the Marciana Library in Venice indicates that the anonymous translator was Terenzia Ghellini.

2. Caminer learned the journalistic trade under the tutelage of her father, Domenico. She began publishing her reviews and translations in the first issue of his literary periodical, the Europa letteraria (1768-73). In 1774, the Europa letteraria became the Giornale enciclopedico, and it remained under Domenico's direction through 1776. Upon assuming direction of the Giornale enciclopedico, Elisabetta moved its publication site to Vicenza, where she lived with her husband, Antonio Turra. She published the Giornale enciclopedico from 1777 to 1782, the Nuovo giornale enciclopedico from 1782 to 1789 , and the Nuovo giornale enciclopedico d'Italia from 1790 until her death in 1796. On Elisabetta Caminer in the context of the history of Venetian journalism, see Marino Berengo, Giornali veneziani del settecento. Linea di sviluppo della stampa periodica veneta (Milano: Feltrinelli, 1962), and Giuseppe Ricuperati, "I giornalisti fra poteri e cultura dalle origini all'Unità" in Corrado Vivanti, ed., Storia d'Italia. Annali 4. Intellettuali e potere, (Torino: Einaudi, 1981), 10851132. For biographical summaries of Caminer's life, see Cesare De Michelis, "Caminer, Elisabetta" in Dizionario biografico degli Italiani, 60 vols.- (Rome: Istituto della enciclopedia italiana, 1974), 17: 236-41, and Catherine M. Sama, "Caminer, Elisabetta" in Rinaldina Russell, ed., Feminist Encyclopedia of Italian Literature (Westport, Conn. and London: Greenwood Publishing Group, 1997), 37-9. For more in-depth studies of Caminer, see Angelo Colla, "Elisabetta Caminer Turra e il 'giornalismo enciclopedico," in Varietà settecentesche. Saggi di cultura veneta tra rivoluzione e restaurazione. Filologia Veneta (Padova: Editoriale Programma, 1991), 83-111; Colla, "Tipografi, editori e librai," in Franco Barbieri and Paolo Preto, eds., Storia di Vicenza, vol. 3.2, (Vicenza: Neri Pozza Editore, 1990), 109-62; Sama, "Women's History in Italian Studies: Elisabetta Caminer and 'The Woman Question"” in La Fusta. Journal of Italian Literature and Culture 10 (fall 1993-spring 1994): 119-36; Rita Unfer-Lukoschik, ed., Elisabetta Caminer Turra (1751-1796). Una letterata veneta per l'Europa (Verona: essedue edizioni, 1998); Unfer-Lukoschik, "L'educatrice delle donne. Elisabetta Caminer Turra (1751-1796) e la 'Querelle des Femmes' negli spazi veneti di fine '700,” Memoire 
dell'Accademia delle scienze di Torino, 5th series, 24 (2000): 249-63. For a biographical monograph on Caminer, see Sama, "Becoming Visible: A Biography of Elisabetta Caminer Turra (1751-1796) During Her Formative Years," Studi veneziani, n.s., 43 (2002): 349-88. For an anthology of Caminer's writing in English, see Elisabetta Caminer Turra, Selected Writings of an Eighteenth-Century Venetian Woman of Letters, ed. and trans. Sama (Chicago: Univ. of Chicago Press, 2003).

3. The Giornale enciclopedico (January 1777) listed the following cities in which the periodical was sold and the local bookseller(s) in each city who supplied it: Bergamo, Bologna, Brescia, Firenze, Fogliano, Lugano, Mantova, Milano, Modena, Napoli, Padova, Parma, Pesaro, Treviso, Turino, Udine, Venice, Vercelli, Verona, and Vicenza. Subscribers could purchase the Giornale enciclopedico either in loose sheets (as individual issues) or bound in volumes (with four months of issues in each volume).

\section{Berengo, Giornali veneziani, x.}

5. An extant copy of Caminer's flysheet is bound in the Biblioteca Nazionale Marciana's copy of the February 1777 issue of the Giornale enciclopedico. Berengo published it in Giornali veneziani, 385-7. An English translation of it appears in Sama, ed., Selected Writings of an Eighteenth-Century Venetian Woman of Letters, 143-46.

6. Collaborators on the Caminer periodicals included naturalists Alberto Fortis and Lazzaro Spallanzani, legal scholar Giovanni Scola, and literary scholars Giuseppe Gennari and Clemente Vannetti, among many others.

7. Berengo, Giornali veneziani, lvi. For a detailed history of the Caminer periodicals, see Berengo, Giornali veneziani, li-lviii, 343-515, and Colla's two essays, “Tipografi, editori e librai” (esp. 149-59) and "Elisabetta Caminer Turra e il giornalismo 'enciclopedico," 83-111. In Italy, the number and variety of periodicals increased dramatically during Caminer's lifetime, and the greatest number of them were produced in Venice. Caminer was born at mid century, during a period of transition in the Veneto from the tradition of purely erudite periodicals (designed to provide acritical information to readers) to a new tradition of journalism with a political-cultural agenda. Indeed, she would be among the leaders in bringing this change to fruition. For a history of journalism in Italy see Valerio Castronovo, Giuseppe Ricuperati, and Carlo Capra, eds., La stampa italiana dal '500 al '800 (Roma-Bari: Edizioni Laterza, 1976) and Alberto Postigliola and Nadia Boccara eds., Periodici italiani d'antico regime (Roma: Società Italiana di Studi sul secolo XVIII Roma, 1986).

8. Only one other Italian woman seems to have preceded Caminer as a professional journalist: Caterina Cracas, who remains nearly completely unstudied by scholars. Three women occupy prominent places in the history of eighteenth-century Italian journalism: Caterina Cracas (1691-1771), Elisabetta Caminer (1751-96), and Eleonora Fonseca Pimentel (1752-99). See Giulio Natali, Storia letteraria d'Italia. Il settecento (Milano: Vallardi, 1929), and Natalia Costa-Zalessow, Scrittrici italiane dal tredicesimo al ventesimo secolo (Ravenna: Longo Editore, 1983).

9. From Caminer's letter to the Florentine man of letters, Giuseppe Bencivenni Pelli, dated 20 October 1770. "il pregiudizio voglia ristrette in confini indiscreti le donne ..." The letter is located in the Archivio di Stato di Firenze, Carteggi Pelli Bencivenni, Fascio 15.

10. From Caminer's review (Europa letteraria [November 1769]: 79-94) of Jean François De Lacroix's Dictionnaire historique portatif des femmes célèbres (Paris: L. Cellot, 1769). “Non v' ha ragione di mascherarci, ed è poi ragionevolissimo, che le Donne trovino una soddisfazione nel vedersi buone a tutto del pari che gli uomini." The importance that Caminer ascribed to this review is evident in its great length (it was one of the longest reviews in the twenty-eight years of the Caminer periodicals) and in the fact that she wrote it to correct an earlier review of the Dictionnaire that had appeared in the April 1769 issue of the Europa letteraria (thus her "re-review" of the Dictionnaire went against the Caminers' general policy of reviewing a work only once). Her father had signed the earlier review, having translated it directly from the March 1769 issue of the Mercure de France. Caminer considered the French journalist's review to have been written "with very little friendliness toward our sex," and she claimed that a "blameless affection for her sex" required her to "speak up for all the others [the women not mentioned in the French journalist's review]" and to choose "the names most deserving of celebrity, and most capable of exciting a praiseworthy emulation" (Europa letteraria [November 1769]: 79).

11. Europa letteraria (November 1769): 90. "E perchè poi dell'ingiustizia loro fossero da più fatti convinti gli uomini, che insieme con molte altre prerogative quella d'insegnare dalle Cattedre vorreb- 
bono esclusivamente arrogarsi, fa il benemerito Autore del nostro Dizionario menzione d'un buon numero di femmine che dalla Cattedra dettarono lezioni nelle più celebri Università . . . . la celeberrima Sig. Laura Bassi che novera fra' suoi discepoli molti de' più rinomati Professori usciti dalla sua Scuola per ispargersi nelle Accademie più illustri d'Italia."

12. A copy of the flysheet is bound in the March 1782 issue of the Giornale enciclopedico located in the Marciana Library in Venice. "O quante volte le mode caratterizzano le teste!"

13. There are no extant subscription lists for Caminer's periodical, but her correspondence reveals that women as well as men subscribed to it. See, for example, Caminer's 19 February 1777 letter to an aristocratic female subscriber (an unidentified "Signora Marchesa") with whom she discusses the details of subscribing to and receiving the Giornale enciclopedico by mail. The letter is located at the Biblioteca Civica di Verona, Autografoteca Veronese B.3. Gasparo Gozzi's correspondence reveals that the Venetian patrician Caterina Dolfin Tron was a subscriber to the Europa letteraria (the earlier version of the Giornale enciclopedico). See Gasparo Gozzi, Lettere, ed. by Fabio Soldini (Varese: Fondazione Pietro Bembo / Ugo Guanda Editore, 1999), 581.

14. Giornale enciclopedico (January 1777): 79, my emphasis. "Sarà . . consolante . . . per una donna spezialmente, il poter parlare d'una traduzione fatta da una persona di quel sesso, che facendo la corte all'ingiustizia degli uomini, sembra rinunzj volontario alla sua porzione di talento e di buon senso per riceverne un frivolo cambio d'ommaggi apparenti, di elogi malfondati, di adulazioni pericolose, legami futili, i quali ci tengono maggiormente ristrette in ischiavitù appunto allora che ci crediamo di ricevere dei tributi, e che n'andiamo orgogliose del nostro impero."

15. This passage echoes directly a poem Caminer published on the occasion of a friend's marriage. Addressing the young bride directly, Caminer wrote: "Fate allows women, too, / To rise up glorious beyond the stars. / But ... we create for ourselves a lowly position, / By becoming slaves to the latest fashions, /And by being intent only upon changing them often, / It is we who make of ourselves a weaker sex." This poem was published in the collection of poetry entitled Poesie per le faustissime nozze del Signor Conte Niccolò Nievo con la Signora contessa Bernardina Ghellini nobili vicentini (Vicenza: Vendramini Mosca, 1774), xix-xxii.

16. On women's roles as readers and writers in the eighteenth century, see Elizabeth Goldsmith and Dena Goodman, eds., Going Public: Women and Publishing in Early Modern France (Ithaca and London: Cornell Univ. Press, 1995); Katheryn Shevelow, Women and Print Culture: The Construction of Femininity in the Early Periodical (London and New York: Routledge, 1989); and Luciano Guerci, La discussione sulla donna nell'Italia del settecento. Aspetti e problemi (Torino: Tirrenia Stampatori, 1987). For a general overview on changes in the publishing industry at this time in the Veneto, see Mario Infelise, L'editoria veneziana nel settecento (Milano: Franco Angeli, 1989). For a general history of female readership in Italy, see Tiziana Plebani, $I l$ "Genere" dei libri. Storie e rappresentazioni della lettura al femminile e al maschile tra medioevo e età moderna (Milano: Franco Angeli, 2001).

17. I am distinguishing fashion periodicals from the more broadly focused periodicals for women—such as The Ladies' Mercury (founded 1693) and the Journal des dames (founded 1759)—that originated in the late seventeenth and early eighteenth centuries in England and France. See Ros Ballaster, Margaret Beetham, Elizabeth Fraser, and Sandra Hebron, eds., Women's Worlds: Ideology, Femininity and the Woman's Magazine (Basingstoke: Macmillan, 1991), 42-74. See also Daniel Roche, La Culture des apparences. Une histoire du vêtement aux XVIIe et XVIIIe siècles (Paris: Fayard, 1989), 456-62.

18. See Grazietta Butazzi, “Mode e modelli culturali nell'ultimo ventennio del secolo XVIII attorno a un'iniziativa editoriale milanese," in Grazietta Butazzi, ed., Giornale delle nuove mode di Francia e d'Inghilterra (Torino: Umberto Allemandi, 1988), cxiii-cxliii.

19. Madeleine Delpierre, Dress in France in the Eighteenth Century, trans. Caroline Beamish (New Haven and London: Yale Univ. Press, 1997), 142-5. See also Roche, Culture des apparences, 451-2. Fashion plates had originated in the seventeenth century, but it was not until the last quarter of the eighteenth century that the production of fashion-plate series exploded and truly manifested the goal of instructing viewers in proper and fashionable attire. An exemplary model of a fashionplate series was the Galeries des modes, published in Paris between 1778 and 1787. On the history and development of fashion plates, see Vyvyan Beresford Holland, Hand-Coloured Fashion Plates, 1770-1899 (London: Batsford, 1955) and Roche, Culture des apparences, 453. It is important to 
distinguish between the fashion plate (designed to advertise new wares) and its older relation, the costume plate (designed to record traditional regional or national costume). Some of the earliest costume prints and catalogs were produced in Caminer's native city, Venice. See Doretta Davanzo Poli, "The Fashion Trades in Venice," in Davanzo Poli, ed., I Mestieri della moda a Venezia. The Arts and Crafts of Fashion in Venice, from the Thirteenth to the Eighteenth Century (London: European Academy and Accademia Italiana, 1997 [1988]), 20-1.

20. Roche, Culture des apparences, 452.

21. The periodical transformed from the Cabinet des modes (1785-86) to the Magasin des modes nouvelles françaises et anglaises (1786-89) and Journal de la mode et du gôेt (1790-92) as indicated by Stefania Ciccone, "Per una lettura del Giornale delle dame e delle mode di Francia," in Butazzi, ed., Giornale delle nuove mode di Francia e d'Inghilterra, lxii. Roche adds that in 1794 it transformed into the Almanach des modes française et anglaise. Roche, Culture des apparences, 454.

22. See Butazzi, “Mode e modelli," cxxviii; Roche, Culture des apparences, 476; Delpierre, Dress in France in the Eighteenth Century, 150-1.

23. Ballaster et al., Women's Worlds, 45.

24. Butazzi describes the fashion periodical's function as a guide in the development of good taste and social graces for members of the bourgeoisie aspiring to social distinction ("Mode e modelli culturali," cxxxvii).

25. Rebecca Messbarger, The Century of Women: Representations of Women in Eighteenth-Century Discourse (Toronto: Univ. of Toronto Press, 2002), 119. I would like to acknowledge Rebecca Messbarger's kind generosity in letting me read a chapter of her book before it was published. The chapter is dedicated to an analysis of the Venetian fashion periodical, La donna galante ed erudita (1786-88).

26. Giornale enciclopedico (January 1778): 65. Caminer was reviewing Clemente Bondi's La Moda, Poemetto (Padova: Stamperia Penada, 1777). "La Moda oggetto futile da per se, ma che parte essenziale del lusso interessa il commercio, che prende varie modificazioni secondo le Nazioni e le teste, che si rende considerabile pel numero de' suoi seguaci, che occupa le menti e distragge i cuori, che si estende a' costumi non meno che a' vestiti, ed accresce gli oggetti della nostra servilità pegli Oltramontani ..." I have taken the liberty of translating the word "Oltramontani" here as "French," since it is clear from the rest of this review that Caminer was speaking specifically of France.

27. Slavish imitation of foreign customs and clothing was a common complaint lodged by detractors of the fashion industry across Europe. In another comment from the same review Caminer was even more precise in her critique of Italians' behavior regarding French fashion (Giornale enciclopedico [January 1778]: 67). She claimed that the fashion dolls arriving in Italy from the "happy river banks" of the Seine were popular among her compatriots because the dolls-standing in for the French fashion industry in general- "[gave] so many who are lazy something to do, and [provided] a happy past time for so many who are bored with themselves."

28. Cissie Fairchilds, "Fashion and Freedom in the French Revolution," in Continuity and Change 15.3 (2000): 421.

29. As the middle classes began to imitate the dress and manners of the upper classes, and servants their masters, it became difficult to determine the social status of individuals simply by their appearance. The blurring of visual distinctions based on social emulation also worked in the other direction. In the last decades of the century, aristocrat and bourgeois alike began to adopt simpler styles of clothing-often made of cotton prints rather than fine silks-that recalled pastoral or peasant wear; see Butazzi, "Mode e Modelli," cxxviii-cxxx. This trend was connected to the twin influences of Rousseau's call for a return to nature and simplicity, and Anglomania with its penchant for elegant simplicity sweeping the continent. The origin of this trend is often attributed to Queen Marie Antoinette and made famous - and infamous-by the 1783 portrait of her by Elisabeth Vigée Lebrun. In the portrait, the queen is wearing a white muslin chemise gown with a high-waisted sash, which came to be known as the "chemise à la reine." See Aileen Ribeiro, Dress in Eighteenth-Century Europe (New York: Holmes and Meier Publishers, 1984), 153.

30. Aileen Ribeiro, Dress and Morality (New York: Holmes and Meier Publications, 1986), 103. 
31. Caminer did not name the publication directly. I am indebted to Venetian fashion historian Doretta Davanzo Poli for helping me to identify it as the Gazzetta toscana. The Gazzetta toscana was published in Florence from 1767 to 1799, and from the 22 March 1777 issue, printer Anton Giuseppe Pagani and bookseller Antonio Fabrini formed a partnership to sell two fashion plates (colored by the artist G. Battista Minghi) with each issue of the gazette to those subscribers who would pay an extra fee. On the Gazzetta toscana and its fashion supplement, see Flavio Orlando, Storia del vestire nel granducato di Toscana al tempo dei Lorena (Milano: Idea 2000 Progetti, 1993), 44-5.

32. From Caminer's letter to Agostino Vivorio, 1 November 1776. The letter is located in the Biblioteca Bertoliana di Vicenza, MS. G. 4.4 .12 (coll. Le 1), 43. "Quella delle mode, che serve per ridere, e per dimostrare sempre più evidentemente, che tutto è contradizione nel mondo, dacchè la Francia ci offre più segnalati esempj di futilità nel tempo medesimo, in cui ci fa invidiare i suoi grand'uomini ..."

33. Giornale enciclopedico (April 1777): 91. "I Sig. Anton Giuseppe Pagani e Antonio Fabrini di Firenze hanno aperta un'associazione, per cui propongono di dare ad ogni due mesi incise, miniate, e colorite le figurine d'uomo e di donna in abito e da Corte e giornaliero, con tutto l'accompagnamento esattissimo da' capelli presi dalla radice fino alla punta delle scarpe inclusivamente, secondo le varie mode cui fanno ad ogni quarto d'ora passar in legge i Dittatori del secolo."

34. From Montesquieu's Persian Letters (1721), letter 99. Quoted here from Delpierre, Dress in France, 7.

35. Giornale enciclopedico (April 1777): 91. "Vittoria, felicità pel nostro sesso, e per quella parte dell'altro che conosce quanto basta i proprj interessi per non darsi un'aria di grandeggiare soverchia dispregiando le amabili donnesche futilità. I Signori della Creazione difatti sono discesi verso le loro umilissime Serve per modo, che divenuti quasi generalmente con esse bagatelle eleganti, non le lasciano al disotto neppure nell'apparenza ... “

36. In a later article (Giornale enciclopedico [January 1778]: 67) Caminer actually refers to such men as "feminine men" or "men-women" (uomini-femmine).

37. Giornale enciclopedico (April 1777): 92. “. . . tutto questo si saprà e si vedrà pella somma considerabile forse in altri casi, ma ristrettissima per quello di cui si tratta ..."

38. Giornale enciclopedico (April 1777): 92. "Si darà esecuzione in Maggio a questa felice impresa, la quale ... gli [agli uomini] solleverà dalle idee gravi, somministrerà nuovi mezzi alle donne ond' esserne sempre le direttrici palesi o segrete, arricchirà i Libraj Fiorentini, e farà del bene altresì al nostro Giornale, il merito del quale non sarà contendibile se potrà riferire sovente di così importanti notizie." For men's control of women's periodicals, see Ballaster et al., Women's Worlds, 46-7.

39. Giornale enciclopedico (April 1777): 91. "il Genio dell'Italia si scuote dal sonno che lo intorpidiva, agguzza gl'ingegni ..."

40. Giornale enciclopedico (April 1777): 91. “Ognuno intende già facilmente i Francesi, quelli che per una strana contraddizione offrono un bizzarro contrasto di solidità e di leggerezza, che perfezionano le Scienze, che estendono le Arti, che si tormentano sulle mode, che producono se non con egual merito con eguale fortuna i grand' uomini e i Petits-Maitres, e che si fanno ammirar indistintamente dagli estatici Italiani, i quali ricopiando i secondi e facendo a' primi di cappello, si consolano contraffacendo gesti e portamenti allo specchio d' essere stati alla fin fine $a b$ initio i loro Maestri."

41. The phrase "their masters from the beginning" might refer to the dominance of the Ancient Roman Empire, to Italian prominence in the Renaissance art world or in fashionable clothing trends. On British imitation of Italian fashions, for example, see Alan Hunt, Governance of the Consuming Passions: A History of Sumptuary Law (New York: St. Martin's Press, 1996), 73.

42. Trimmings of various kinds used to decorate dresses.

43. Long veils for women that descended from the top of the head to just below the shoulders and were attached to the head with a hair comb.

44. Depending on the length of the shirt collar, it could be wrapped around the neck once or many times, thus determining the thickness of the collar. 
45. In other words, with an affected, perhaps overly gracious air or with a more sober, formal tone. The implication behind this phrase is the contrast between French and English fashions.

46. An Italian braccio refers to a wooden measuring tool for cloth, which measured about fifty to seventy centimeters long, depending on the type of cloth and the city. Doretta Davanzo Poli, "The Fashion Trades in Venice," 15.

47. Giornale enciclopedico (April 1777): 91-2. I would like to acknowledge the gracious assistance I received in the translation of this passage from Venetian fashion historian Doretta Davanzo Poli and, at the Rhode Island School of Design Museum, Susan Hay and Madelyn Shaw. "Colori, galloni, cuffie, ricami, mantiglie, cravatte, merletti, borsellini, ventagli, cappelli piccioli, cappelli grandi, guardinfanti, non guardinfanti, piume, non piume, abiti larghi e stretti, tagli lunghi e tagli corti, acconciature d' ogni genere, tutto sarà espresso, tutto dilucidato con provvide spiegazioni, e note opportune; gli uomini sapranno se debbono andar a trattare i loro affari col collo grosso o sottile, col passo di minuetto, o coll' aria inglese; le donne se diriggeranno meglio le loro famiglie con a molta circonferenza nel vestire o con poca, ed a qual braccio italiano debbe riferirsi l'altezza del loro tupé ..."

48. See Ribeiro, Dress in Eighteenth-Century Europe, 150-60, and Ribeiro, Dress and Morality, $106-7$.

49. We do not know when the original portrait of Caminer was painted (the status of its survival and/or location is unknown), nor when the two surviving etchings of it were made. However, given Caminer's appearance in terms of age, we may surmise that she would have been in her late twenties or early thirties at the time this portrait was made, thereby dating the portrait to the late 1770 s or early 1780 s, when the Turkish-style dress was fashionable.

50. As early as the seventeenth century, fashionable appearance served as a means of advertising one's success. See Patricia Allerston, "Clothing and Early Modern Venetian Society," Continuity and Change 15 , no. 3 (2000): 367-90.

51. From Caminer's letter to Giuseppe Pelli Bencivenni, 19 January 1771 . The letter is located in the Archivio di Stato di Firenze, Carteggi Pelli Bencivenni, Fascio 16. "O bella o brutta ch'io mi sia, se son brutta in vano vorrei supplire coll' arte a' difetti della natura, se non lo sono affatto, ne ho piacere perchè anche questo può essere un vantaggio . . . . Non crediate però ch' io abbia una di quelle Filosofie ch' io chiamo villane; no; si dee vivere, ed aver pulizia, ma non sagrificare a questa il tempo dovuto all'amicizia."

52. On the importance of correspondence to membership in the Republic of Letters, see Dena Goodman, The Republic of Letters. A Cultural History of the French Enlightenment (Ithaca and London: Cornell Univ. Press, 1994).

53. This is evident in the fact that copies were immediately made of the Cabinet des modes in English (The Fashionable Magazine, London, 1786) and in German (Journal des Luxus und der Moden, Weimar, 1786). See Roche, Culture des apparences, 464-5 and Butazzi, "Mode e modelli," cxiv.

54. This type of liberal borrowing and translating was a common practice in the business of periodical publication in the eighteenth century.

55. The Milanese periodical was published from 1786 to 1794 and underwent two title changes. It transformed from the Giornale delle dame e delle mode di Francia (1786) to the Giornale delle dame e delle mode di Francia e d'Inghilterra (1786-93) to the Giornale delle mode principali d'Europa dedicato alle dame Italiane (1793-94). Butazzi, "Mode e modelli," cxiii. A copy of the Giornale delle dame e delle mode is located in the Biblioteca Trivulziana in Milan. The Donna galante ed erudita was published between 1786 and 1788 in Venice and sold in the San Benedetto bookshop of the publisher G. Albrizzi. A copy of the Donna galante ed erudita is located in the Marciana library in Venice. Scholars have not been able to identify the editor of the Milanese periodical; as we shall see, the Venetian editor's identity is important for our discussion.

56. For comparisons of the Cabinet des modes and its Italian imitators, see Butazzi, ed., Giornale delle nuove mode di Francia e d'Inghilterra and De Michelis, ed., La donna galante ed erudita. Giornale dedicato al bel sesso (Venezia: Marsilio Editori, 1983). 
57. Nuovo giornale enciclopedico (May 1786): 121-4.

58. Reviews in the Caminer periodicals were generally two to six pages in length.

59. Nuovo giornale enciclopedico (May 1786): 121-2. "Fu pubblicato a Milano il Manifesto di un Giornale delle Dame e delle Mode di Francia, oggetti che vanno insieme naturalmente, come ognun vede. Esso abbraccierà Novelle morali e dilettevoli, romanzetti sensibili, racconti graziosi tradotti ed originali; e queste belle cose per procurar il bene morale delle donne. Più: Istruzioni al bel sesso, nelle quali saranno legate insieme le cose della virtù con quelle della toeletta. Qualcuno crederebbe ch' esse potessero far alle pugna; ma non sarà. Più: Poesie, che chi ha scritto il Manifesto definisce parte poetica, per cominciar ad erudir il bel sesso: esse dovranno vivificare il cuore delle donne, come quelle che saranno amorose, facete, e bizzarre; e perchè possano vivificarlo in sano modo, sarà sbandito da esse il sagro, il filosofico, e lo stucchevole, che, com' è noto, è tuttuno. Più: Varietà galanti, vale a dire Letteratura, Musica, Pittura, aneddoti, e tratti di spirito, che saranno delineati in modo bizzarro. Più: Mode correnti di Francia, articolo che vien dichiarato il più interessante; e quì si avranno rami, descrizioni, e tutto ciò che può contribuire al raddrizzamento delle teste delle Signore."

60. Nuovo giornale enciclopedico (May 1786): 122. "Noi ci lagnavamo, povere donne, ch' era trascurata la nostra educazione: il Cielo ha provveduto anche per noi. Buoni genitori, in qual età felice nascono le vostre figliuole! Con 24 lire all'anno voi le preserverete dalla noja, dalla goffaggine, e formerete loro lo spirito e il cuore."

61. Nuovo giornale enciclopedico (May 1786): 122. "Abbiamo creduto di potere scherzar fino ad ora; ma giunti al passo seguente dell'incredibile Manifesto, non possiamo nascondere una ragionevole indignazione. I Leggitori lo scorrano, e chi vuol dopo questo saggio Giornale lo pigli.”

62. Nuovo giornale enciclopedico, (May 1786): 122-3. "'In tal guisa essendo per essere questo Giornale il trionfo delle Dame Italiane non si dispera della graziosa loro accoglienza, e di quella degli amici di questo rispettabilissimo sesso. In un'Opera consagrata al passatempo delle donne sarà facile che un'altra donna trovi il modo da distinguersi; desidera di mascherare l'utile col dilettevole, e sarà per lei una vera sorte il poter dire, che ad esse prepara un ozio che potrebbe innamorare il loro spirito, lasciar qualche traccia in fondo del loro cuore, e dare altresì un reale valore ad una momentanea distrazione. Dedicato questo lavoro alle Grazie, non sarà nemmeno privato di quel tuono d'indulgenza che le caratterizza; così la critica non si presenterà che disarmata . . . . e sempre lo scopo principale di quest'Opera sarà quello d'istruire il bel sesso colla piacevolezza, e colla galanteria." "

63. Caminer was indignant about such valorization of appearance over reality. Daniel Roche describes two such opposite elements or values of fashion: that of pleasure/appearance (plaire/paraitre) and that of instruction/being (instruirelêtre). See Roche, Culture des apparences, 465 . For the relationship between fashion and the practice of masking, see Messbarger, The Century of Women, 12732 .

64. Messbarger, The Century of Women, 106.

65. Messbarger, The Century of Women, 106.

66. I would like to acknowledge here my use of Roche's phrase "Liberty, Equality, Frivolity!" (Culture des apparences, 471) in my article's title.

67. Nuovo giornale enciclopedico (May 1786): 123. "Per colmo di stravaganza sembra che l'Autrice di questo Giornale sia una donna. Non eravamo trattate con abbastanza dispregio dagli uomini senza che ci riducessimo all'avvilimento di mostrarci disprezzevoli da per noi?"

68. The editor self-identified as female, since she used feminine gendered nouns and adjectives to describe herself. To date, we do not have conclusive evidence as to whether this was a guise or not. Such gender masking was not an uncommon practice in eighteenth-century periodical literature. However, we might infer from Caminer's shock that, at least in 1786 Italy, it would have been a new phenomenon to see a female editor of a fashion periodical.

69. Of course, this reveals Caminer's bias regarding what kinds of accomplishments she deemed positive for women. As we shall see with her next review, other women were beginning to view the fashion periodical as a new model for female empowerment. 
70. Nuovo giornale enciclopedico (July 1786): 114-15. Caminer was reviewing the manifesto which described the goals and the ideology of the forthcoming periodical. To my knowledge the manifesto itself has never been found. A comparison of Caminer's review of the manifesto and Cornoldi's apology for the periodical-which she published in the first issue of the Donna galante ed erudita-reveals that the manifesto and the apology contained much of the same phrasing. Our analysis of Caminer's review of the manifesto is enhanced by this fact, as we can look more subtly into her rather cryptic critique.

71. See Colla, “Elisabetta Caminer Turra e 'il giornalismo enciclopedico," 100-08.

72. Gioseffa Cornoldi wrote: "Finally, my pen whispers in my ear that I, too, can scribble. It also warns me that I must restrict myself to feminine literature. What could be more appropriate than that of fashion, and even more so since we also have a new way of writing." I quote the original Italian from De Michelis, ed., La donna galante ed erudita, 3.

73. Messbarger, The Century of Women, 115-16.

74. Messbarger, The Century of Women, 132.

75. In a 1783 review of an advice book for new wives and mothers, Caminer registered this distress at women's misguided embrace of fashion's demands: "It is pitiful to see to see how gallant women torture themselves to invent fantastic decorations and to look like frauds or something worse. Their misguided delight in making themselves seen blinds them to the point that they cannot read the derision, the disdain on the physiognomies of all who look at them attentively, and who unfortunately often judge their customs by those appearances which place them at the level of the most vile creatures" (Nuovo giornale enciclopedico [September 1783]: 43-4).

76. I borrow this apt phrase from Messbarger, The Century of Women, 112.

77. Put in contemporary terms, the differences in ideology and format between Caminer's and Cornoldi's periodicals parallel almost exactly those of today's Ms. and Cosmopolitan magazines.

78. Nuovo giornale enciclopedico (July 1786): 114-15. "Per invogliar le Signore, che debbono essere le principali posseditrici di codesto Giornale, la Compilatrice indica gli articoli de' quattro primi fogli, e sono: Novelle non morali. La prima è: Come fare? Pennellata critica sopra $i$ Cavalieri serventi. Modi di conservare la bellezza delle Donne.-Trenta cose (da desiderarsi congiunte) perché una Donna sia perfetta.-Qual è la qualità più propria a render felice un matrimonio? ... Erudizione: Sponsali degli antichi Romani.-Apologia de' moderni maritaggi.-Libri nuovi a portata del sesso femmineo ..."

79. Nuovo giornale enciclopedico (July 1786): 115. "Le Signore debbono troppo ritrovarvi il loro conto per non concorrere a render numerosa l'associazione."

80. We may consider the progression from Caminer's 1777 confidence in her readers' skepticism-“victory for our sex!"-to her comment on the Milanese periodical— "whoever wants it after reading this, grab it" - to the tone of resignation in this review of the Venetian periodical.

81. In the words of Kathryn Shevelow (Women and Print Culture, 20): "It . . . is crucial for a feminist evaluation of the eighteenth century to ... examine the degree to which such writing [women's writing] received authority through its very implication in the emerging cultural construction of femininity."

82. Mary Wollstonecraft, cited in David Lorne Macdonald and Kathleen Scherf, eds., The Vindications. The Rights of Men. The Rights of Woman. (Toronto: Broadview Literary Texts, 1997), 123.

83. Nuovo giornale enciclopedico d'Italia (October 1792): 125-6. "E' la campionessa del sesso questa Signora. Ma che otterà [sic] ella? Le rivoluzioni non sono in tutti i generi facili o frequenti." 